\title{
Production and quality of corn silage with forage and pigeon peas in a crop-livestock system
}

\section{Produção e qualidade da silagem de milho com braquiárias e feijão guandu em sistema integrado de produção agropecuária}

Vinicius Carreteiro Gomes ${ }^{1}$; Paulo Roberto de Lima Meirelles²; Ciniro Costa ${ }^{2}$; Juliana da Silva Barros ${ }^{1 *}$; André Michel de Castilhos $^{3}$; Daniel Martins de Souza ${ }^{1}$; Renata Tardivo ${ }^{1}$; Cristiano Magalhães Pariz ${ }^{3}$

\section{Highlights}

Consortia did not interfere with the productivity of corn for silage.

The silage with pigeon peas had a higher concentration of crude protein.

A 0.40 m corn cutting height provided greater participation of the grain fraction.

\begin{abstract}
The objective of this study was to evaluate maize in consortium with forage in a crop-livestock system for silage production, with subsequent formation of pasture. The experimental design comprised randomized blocks, with four replications, two types of corn cultivation, intercropped with two Brachiaria species (marandu grass and convert grass), and with and without intercropping with the pigeon pea (Cajanus cajan) BRS Mandarin. Dry matter productivity, the morphological composition of the corn, the botanical composition of the Brachiaria and pigeon peas, and the bromatological composition of the silage and Brachiaria were evaluated, as well as the losses caused by effluents. The consortia did not interfere with the productivity of corn for silage, and the silage from the consortium with pigeon peas exhibited a higher concentration of crude protein, demonstrating that the modality of the integrated agricultural production system of corn culture with Brachiaria and pigeon peas is an alternative to increase the protein content of the ensiled material and provide greater diversity of the remaining forage.
\end{abstract}

Key words: Consortium. Forage grasses. Leguminous.

1 Doctoral Student at the Post-Graduation Program in Animal Science at the São Paulo State University, UNESP, College of Veterinary Medicine and Animal Science, Botucatu, SP, Brazil. E-mail: vinicius2gomes@gmail.com; juliana.1234barros@gmail.com; souzadm.zoo@gmail.com; reh_tardivo@hotmail.com

2 Profs., UNESP, College of Veterinary Medicine and Animal Science, Dep. of Animal Nutrition and Breeding, Botucatu, SP, Brazil. E-mail: paulo.meirelles@unesp.br; ciniro@fmvz.unesp.br

${ }^{3}$ Researcher, Departament of Animal Nutrition and Breeding, UNESP, Botucatu, SP, Brazil. E-mail: michel.castilhos@ unesp.br; cmpzoo@gmail.com

* Author for correspondence

Received: July 21, 2020 - Approved: Oct. 04, 2020 


\section{Resumo}

Objetiva-se avaliar o milho em consórcio com forrageiras em sistema integrado de produção agropecuária para produção de silagem, com posterior formação da pastagem. O delineamento experimental foi em blocos casualizados, com quatro repetições sendo duas modalidades de cultivo do milho, consorciado com duas braquiárias (capim marandu e capim convert) e, com e sem consórcio com feijão guandu (Cajanus cajan) cv. BRS Mandarim. Foi avaliada a produtividade de massa seca, a composição morfológica do milho, a composição botânica das braquiárias e do feijão guandu, bem como a composição bromatológica das silagens e das braquiárias e, as perdas por efluentes. Os consórcios não interferiram na produtividade do milho para silagem, sendo que a silagem proveniente do consorcio com o feijão guandu apresentou maior concentração de proteína bruta, evidenciando que a modalidade do sistema integrado de produção agropecuária da cultura do milho com braquiárias e feijão guandu constitui alternativa para aumentar o teor de proteína do material ensilado e proporcionar maior diversidade da forragem remanescente.

Palavras-chave: Consórcio. Gramíneas forrageiras. Leguminosa.

\section{Introduction}

Integrated crop-livestock systems (SIPA) are supported by an ecological, biophysical, socioeconomic conceptual diversity, with fundamental participation in agriculture for hundreds of years (Food and Agriculture Organization of the United Nations [FAOSTAT], 2010). In these systems, the consortium is established annually, and sowing of the annual crop can be implemented simultaneously or approximately 10 to $20 \mathrm{~d}$ after its emergence (Kluthcouski et al., 2000) for a consortium of grain-producing crops (corn, sorghum, millet, rice, and soybeans) and tropical forages. These mainly consist of the Urochloa genus (syn. Brachiaria) because of differences in growth in time and space and the accumulation of biomass between species (Pereira et al., 2011).

Research results based on the use of leguminous forage species in a consortium have verified maintenance or increase in productivity (Mhlanga et al., 2016). Including a legume, such as pigeon peas, can increase the nitrogen $(\mathrm{N})$ supply in the soil by temporarily immobilizing $\mathrm{N}$ through biological fixation, thereby reducing the use of nitrogen fertilizers in subsequent cultivation (Oliveira, Kluthcouski, Favarin, \& Santos, 2011). Legumes can be used to feed ruminants in the form of silage, increasing the crude protein content and reducing the use of protein sources that increase the cost of diets (Quintino, Zimmer, Costa, Almeida, \& Bungenstab, 2013).

Studies that evaluated the corn consortia have focused primarily on grain productivity instead of prioritizing dry mass productivity and nutritional value of the forage in succession. In the literature, few studies have been conducted (Oliveira et al., 2011; P. M. Costa et al., 2012; Kappes \& Zancanaro, 2015; Garcia et al., 2016; Guimarães, Ciappina, Anjos, Silva, \& Pelá, 2017) that have evaluated the simultaneous consortium of three species, in an area with desiccated pasture; thus, optimizing mechanization in the area for silage production. Therefore, it is essential to conduct studies that evaluate the accumulation of the mass of three species in a consortium on the productivity of corn and the quality of silage from the consortia. 
The consulted works (Chioderoli, Mello, Grigolli, Silva, \& Cesarin, 2010; Crusciol et al., 2013; N. R.Costa et al., 2017) that adopted this agricultural production system primarily evaluated the use of Urochloa brizantha, $U$. decumbens, and $U$. ruziziensis grasses, and there is a lack of studies with new grasses that appear on the market as options for SIPA, such as the Urochloa (hybrid) Convert HD364 ${ }^{\circledR}$.

Given the above, the goal of this study was to analyze the corn crop for silage production in a consortium with two brachiarias (marandu grass and convert grass) and a legume (pigeon pea) in SIPA.

\section{Materials and Methods}

The experiment was conducted at the Fazenda Experimental Lageado, which belongs to the Faculty of Veterinary Medicine and Zootechnics (FMVZ - UNESP) in the municipality of Botucatu - SP (22 $51^{\circ} 01^{\prime \prime} S$ and $48^{\circ} 25^{\prime} 28^{\prime \prime} \mathrm{W}$, at an altitude of $777 \mathrm{~m}$ ). According to the Köppen classification, the predominant climate in the region is the Cwa type (tropical high altitude, with dry winters, and hot and rainy summers), the average temperature of the hottest month is over $22{ }^{\circ} \mathrm{C}$ (Cunha \& Martins, 2009). The climatic data during the experimental period are provided in Table 1.

The soil of the area is classified as a Latossol Red dystrophic (H. G. Santos et al., 2018) with 280, 90, and $630 \mathrm{~g} \mathrm{~kg}^{-1}$ sand, silt, and clay, respectively. The experimental area had been fallow for more than 10 years, with Urochloa decumbens Basilisk. The experimental design comprised randomized blocks, in a $2 \times 2$ factorial scheme, with four replications. The treatments corresponded to the cultivation of corn for the production of silage in consortium with two brachiarias: marandu grass (Urochloa brizantha Marandu) and the grass-converted HD364 ${ }^{\circledR}$ hybrid, with and without intercropping with pigeon peas (Cajanus cajan) BRS Mandarin, totaling four treatments. Each plot consisted of $2,000 \mathrm{~m}^{2}$, being $20 \mathrm{~m}$ wide and $100 \mathrm{~m}$ long.

\section{Table 1}

\section{Meteorological data from the trial period}

\begin{tabular}{|c|c|c|c|c|c|c|c|}
\hline \multirow[b]{3}{*}{ Rated feature } & \multicolumn{7}{|c|}{ Month } \\
\hline & Nov. & Dec. & Jan. & Feb. & Mar. & Apr. & May. \\
\hline & \multicolumn{7}{|c|}{$2014-2015$} \\
\hline Rainfall & 144 & 265 & 256 & 252 & 265 & 46 & 99 \\
\hline Minimum average temperature $\left({ }^{\circ} \mathrm{C}\right)$ & 28.1 & 28.6 & 31.7 & 28.4 & 27.1 & 27.0 & 23.4 \\
\hline Maximum mean $\left({ }^{\circ} \mathrm{C}\right)$ & 13.9 & 15.5 & 19.1 & 18.1 & 17.2 & 16.1 & 13.4 \\
\hline Average temperature of 60 years & 21.8 & 22.6 & 22.7 & 23.5 & 22.0 & 19.5 & 18.0 \\
\hline Radiation (MJ m²) & 636 & 650 & 756 & 518 & 508 & 538 & 400 \\
\hline
\end{tabular}


In October, agricultural operations were conducted by plastering with $30 \mathrm{~kg} \mathrm{ha}^{-1}$ and liming with $2,000 \mathrm{~kg} \mathrm{ha}^{-1}$ of dolomitic limestone (PRNT 95\%). At the end of November, the plants present in the area for straw formation were desiccated with the application of the herbicides glyphosate and 2,4-D amine [isopropylaminesaltofN- (phosphonomethyl) glycine] at doses of 1,440 and $670 \mathrm{~g} \mathrm{ha}^{-1}$ of the acid equivalent, respectively, using a spray volume of $200 \mathrm{~L} \mathrm{ha}^{-1}$.

In December, the 2B587 PW (early) corn hybrid was sown at a depth of $0.03 \mathrm{~m}$, using a seeder-fertilizer machine for a notillage system, equipped with a furrow opening mechanism, at a density of 80,000 seeds ha-1, with $0.45 \mathrm{~m}$ spacing.

Brachiaria seeds were sown at 10.0 $\mathrm{kg} \mathrm{ha}^{-1}$ with 600 points of cultural value per hectare. The seeds of marandu grass and convert grass were mixed with the fertilizer just before sowing. The mixture was stored in the fertilizer compartment of the seederfertilizer and deposited at a depth of $0.08 \mathrm{~m}$. Thus, the grass seeds were located below the corn seeds, following the recommendations of Kluthcouski et al. (2000) and Borghi and Crusciol (2007), to delay their emergence in relation to the corn crop, thereby reducing the probable competition of the forage species during the initial period of crop development.
In another mechanized operation, pigeon peas were sown between the lines of corn at a spacing of $0.45 \mathrm{~m}$ and depth of $0.03 \mathrm{~m}$. Fifteen seeds per meter were used, totaling approximately $60 \mathrm{~kg} \mathrm{ha}^{-1}$ of seeds, as recommended by Oliveira et al. (2011).

Mineral fertilization in the sowing furrows followed the recommendations of Raij, Cantarella, Quaggio and Furlani (1997) for the cultivation of corn for grain production. The full emergence of corn seedlings occurred 7 $\mathrm{d}$ after planting. The full emergence of pigeon peas, marandu, and convert grass seedlings occurred at 12, 22, and $24 \mathrm{~d}$ after planting, respectively. Because of the amount of straw on the soil surface, there was no emergence of annual broad-leaved weeds, and it is not necessary to apply herbicides during the postemergence period for corn culture.

After $21 \mathrm{~d}$ of emergence (DAE), the maize plants were at the V4 stage (four fully unfolded sheets), and mineral topdressing was manually applied along the lines of maize plants without incorporation, following the recommendations of Raij et al. (1997).

Soil fertility assessments were conducted at a depth of $0-0.20 \mathrm{~m}$ before plastering and liming and after planting, through the collection of 20 sounding profiles to constitute a sample composed of the entire area, according to the methodology of Raij, Andrade, Cantarella and Quaggio (2001). The results are shown in Table 2.

\section{Table 2}

Soil analysis of the experimental area before planting and after cover fertilization

\begin{tabular}{ccccccccccc} 
Time & $\begin{array}{c}\mathrm{pH} \\
\mathrm{CaCl}^{2}\end{array}$ & $\begin{array}{c}\mathrm{M} . \mathrm{O} . \\
\mathrm{g} \mathrm{dm}^{-3}\end{array}$ & $\begin{array}{c}\mathrm{P}_{\text {resina }} \\
\mathrm{mg} \mathrm{dm}^{-3}\end{array}$ & $\mathrm{H}+\mathrm{Al}$ & $\mathrm{K}$ & $\begin{array}{c}\mathrm{Ca} \\
\mathrm{mmol}\end{array}$ & $\begin{array}{c}\mathrm{Mg} \\
\mathrm{cdm}^{-3}\end{array}$ & $\mathrm{SB}$ & $\mathrm{CTC}$ & $\mathrm{V} \%$ \\
\hline 1 & 4.2 & 28.2 & 6.5 & 82.0 & 1.6 & 17.2 & 6 & 24.7 & 106.7 & 23.0 \\
2 & 5.1 & 38.1 & 12.2 & 41.4 & 1.0 & 31.5 & 15.8 & 48.3 & 89.7 & 53.8 \\
\hline
\end{tabular}

1: before plastering and liming; 2 : after planting. 
Before harvest, the final plant population (PFP) and the final number of ears (NE) per hectare were determined by counting plants and ears in the four central lines, at $6 \mathrm{~m}$ long per plot $\left(10.8 \mathrm{~m}^{2}\right)$. Additionally, the height of plants (AP) and the insertion of the main ear (IEA) were determined with a graduated ruler. Subsequently, the plant fraction above $0.40 \mathrm{~m}$ was sampled in the four central lines, which were $6 \mathrm{~m}$ in length per plot, to determine the total green mass productivity (PMVT) and extrapolated this to $\mathrm{kg} \mathrm{ha}^{-1}$. The percentage of grains in the silage was measured through manual threshing. A representative sample was placed in a forced ventilation oven at $65^{\circ} \mathrm{C}$ until a constant weight was attained to determine the total dry mass (PMST) yield of forage and extrapolated it to $\mathrm{kg} \mathrm{ha}^{-1}$. Dividing the dry mass of grains, in $\mathrm{kg} \mathrm{ha}^{-1}$, by the NE per hectare, the production of dry mass (PMS) of grains in $\mathrm{kg}$ $\mathrm{ha}^{-1}$ was determined. The same methodology was used to evaluate the residue below 0.40 $\mathrm{m}$ from the cut, represented by stalks of corn and the remaining brachiaria and pigeon pea plants.

In April, the material to be ensiled was manually cut at a height of $0.40 \mathrm{~m}$ above ground level, as recommended by Pariz et al. (2017) for SIPA, to benefit the regrowth of grass after harvest of corn for silage. Additionally, the lower extraction of potassium from the area (Jaremtchuk et al., 2008) was determined. The timing of harvest for the treatments was determined by visual observation of the corn grain milk line, which occurred 114 d after sowing, with $1 / 4$ of the milky grain.

The harvested forage, above $0.40 \mathrm{~m}$ for silage, was chopped in a stationary chopper coupled to the power outlet of the tractor. Sampling was then conducted to determine the dry matter in an oven at $65^{\circ} \mathrm{C}$.
To prepare the experimental silo, PVC at $10 \mathrm{~cm}$ in diameter and $60 \mathrm{~cm}$ in length was coupled with PVC caps at each end to ensure a proper seal. The upper cover contained the "Bunsen" type exhaust valves for the escape of gases from fermentation. In the lower internal part of the silos, $400 \mathrm{~g}$ bags of sterile fine sand made with non-woven fabric (TNT) were introduced, separated by a nylon screen to quantify the possible effluent losses generated during ensiling. Compaction was conducted using a hydraulic press, providing an average density of $600 \mathrm{~kg}$ of green mass per cubic meter. The tare of the experimental silos (tube + cover + dry sandbag + screen) was measured before filing with forage and the weight of the filled and closed tubes was used to determine the recovery of dry matter and losses by gases and effluents (Jobim, Nussio, Reis, \& Schmidt, 2007).

After $59 \mathrm{~d}$ of ensiling, the bins were weighed, to quantify gas losses, followed by opening for quantification of losses of effluent by suitable equations from M. C. Santos et al. (2008). When the experimental silos were opened, the upper content $(0.10 \mathrm{~m})$ of each silo was discarded. The silage was homogenized and sampling proceeded by breaking it down into two sub-samples. The first sub-sample was stored in a plastic bag and immediately frozen at $-20{ }^{\circ} \mathrm{C}$ to determine the titratable acidity (AT) ( $\mathrm{NaOH} \mathrm{mL}$ ) using the methodology described by Silva and Queiroz (2002).

The second sample was weighed, packed in a paper bag, and dried in an oven with forced ventilation at a temperature of 65 ${ }^{\circ} \mathrm{C}$ until a constant weight was obtained for the dry matter of the material. This sample was then ground in a Wiley mill and sieved through a $1 \mathrm{~mm}$ sieve. Following this, it was dried at $105{ }^{\circ} \mathrm{C}$ for determination of dry matter (DM), 
ash (MM), (EE) according to the Association of Official Analytical Chemists [AOAC] (1995), crude protein $(\mathrm{PB})$ was determined using the micro Kjeldahl method, neutral detergent fiber (NDF), acid detergent fiber (ADF), and lignin (LIG) were determined according to Van Soest (1994). The in vitro digestibility of DM was determined according to the ANKOM ${ }^{\circledR}$ protocol and using the DAISYII incubator and $\mathrm{pH}$ in a digital pot, according to the technique described by AOAC (1995). The total digestible nutrient content was estimated according to the equation adopted by the National Research Council [NRC] (2001).

The electrical conductivity (EC) of silage was measured to quantify the intensity of cell disruption performed according to Jobim et al. (2007). In the solutions obtained from the sample filtration, an indirect reading of the number of free electrolytes was performed in the solution with a conductivity meter (MS Tecnopon $^{\circledR}$ ).

The data were submitted to the Shapiro-Wilk normality test in the UNIVARIATE procedure of the SAS program (Statistical Analysis System [SAS Institute], 2014), with the indicated results showing that all data were distributed normally ( $\mathrm{W}>0.90)$. Data for all variables were analyzed using the PROC MIXED procedure of SAS and the Satterthwaite approximation to determine the degrees of freedom of the fixed effect tests. The consortia used and the fodder were considered fixed effects. The data were analyzed using the repetitions (consortium $\times$ forage) as random effects. The results were presented using the "LSMEANS" and separated by the Student's t-test at a $5 \%$ significance level.

\section{Results and Discussion}

The final plant population (PFP), ear number (NE), and grain dry mass productivity (PMS) did not differ $(P>0.05)$ by consortia (Table 3). Garcia et al. (2013) used corn intercropped with tropical forage, including Megathyrsus maximum Tanzania, Mombaça, U. ruziziensis, and marandu grass sown simultaneously at a spacing of $0.90 \mathrm{~m}$, observed significant differences in grain yield of 8.263, 8.020, 8.224, and $7.834 \mathrm{~kg} \mathrm{ha}^{-1}$, respectively, which were slightly higher than the values in this study, with an average of $7.318 \mathrm{~kg} \mathrm{ha}^{-1}$. Oliveira et al. (2011) also found no influence on the NE of corn intercropped with marandu grass.

Plant height (AP) of corn (Table 3) was different $(P<0.05)$ between brachiarias; however, there was no interaction of consortium, with the highest values encountered in the treatment with grass conversion. This was possibly caused by lower competition among corn plants for edaphoclimatic factors because of the lower numerical population of plants per ha $(55,572)$ in relation to that of other treatments, with an average of 67,309 plants per ha. 


\section{Table 3}

\section{Corn production and productivity components for silage production intercropped with two brachiaria} and with and without pigeon peas

\begin{tabular}{|c|c|c|c|c|c|c|c|c|}
\hline \multirow[b]{3}{*}{ Variable } & \multicolumn{4}{|c|}{ Corn } & \multirow[b]{3}{*}{ EPM } & \multicolumn{3}{|c|}{ P-value } \\
\hline & \multicolumn{2}{|c|}{ Without Guandu } & \multicolumn{2}{|c|}{ With Guandu } & & \multirow[b]{2}{*}{ Consortium } & \multirow[b]{2}{*}{ Forage } & \multirow[b]{2}{*}{$C^{*} F$} \\
\hline & Marandu & Convert & Marandu & Convert & & & & \\
\hline \multicolumn{9}{|l|}{ Corn } \\
\hline PFP & 68.629 & 63.882 & 69.418 & 55.572 & 7.832 & 0.6397 & 0.2582 & 0.5722 \\
\hline NE & 61.111 & 61.111 & 62.037 & 55.556 & 7.833 & 0.7727 & 0.6864 & 0.6864 \\
\hline AP & 2.01 & 2.15 & 2.03 & 2.22 & 0.67 & 0.5044 & 0.0257 & 0.6699 \\
\hline AIE & 0.88 & 0.86 & 0.85 & 0.96 & 0.51 & 0.5227 & 0.3408 & 0.2080 \\
\hline Grain PMS & 7.491 & 6.177 & 8.245 & 7.358 & 0.850 & 0.2776 & 0.2202 & 0.8066 \\
\hline Prop. thatched & 12.53 & 15.41 & 14.12 & 13.29 & 0.87 & 0.7691 & 0.2637 & 0.0548 \\
\hline Prop. of vegetable & $37.33 a$ & $32.54 b$ & $28.39 c$ & $33.52 b$ & 1.52 & 0.0226 & 0.9148 & 0.0069 \\
\hline Prop. grain & 44.78 & 45.79 & 52.00 & 47.33 & 1.57 & 0.0169 & 0.2670 & 0.0979 \\
\hline Prop. of cob & 5.35 & 6.26 & 5.48 & 5.86 & 0.72 & 0.8534 & 0.3933 & 0.7248 \\
\hline Residue & 2.365 & 1.859 & 2.363 & 2.340 & 257.01 & 0.3693 & 0.3229 & 0.3666 \\
\hline PMS & 13.404 & 10.536 & 12.504 & 12.378 & 1.415 & 0.7955 & 0.4823 & 0.5102 \\
\hline \multicolumn{9}{|l|}{ Brachiaria } \\
\hline AP & $0.70 b$ & $0.42 c$ & $0.74 b$ & $0.87 a$ & 0.66 & 0.0016 & 0.2721 & 0.0069 \\
\hline Proportion & 1.70 & 5.18 & 0.87 & 2.05 & 0.18 & 0.3127 & 0.2375 & 0.5500 \\
\hline Harvested & 249.42 & 455.08 & 107.47 & 243.19 & 82.49 & 0.2763 & 0.2963 & 0.8254 \\
\hline Residue & 111.10 & 204.77 & 72.00 & 120.99 & 55.14 & 0.2871 & 0.2202 & 0.6924 \\
\hline PMS & 360.52 & 659.86 & 179.47 & 364.10 & 127.14 & 0.2449 & 0.2381 & 0.7738 \\
\hline \multicolumn{9}{|l|}{ Pigeon pea } \\
\hline AP & & & 1.79 & 1.77 & 0.13 & . & 0.9303 & . \\
\hline Proportion & & & 6.56 & 9.89 & 1.71 & . & 0.3495 & . \\
\hline Harvested & & & 945.87 & 1.383 & 289.53 & . & 0.4645 & . \\
\hline Residue & & & 323.84 & 502.19 & 69.84 & . & 0.2258 & . \\
\hline PMS & & & 1.269 & 1.885 & 345.51 & . & 0.3903 & $\cdot$ \\
\hline PMST & 13.653 & 10.991 & 13.557 & 14.004 & 1.437 & 0.3302 & 0.4559 & 0.3007 \\
\hline PMVT & 31.881 & 31.742 & 38.999 & 35.479 & 3.682 & 0.1547 & 0.6593 & 0.6234 \\
\hline
\end{tabular}

Values with the same letters in a row do not differ from each other based on the t-test $(0.05 \%)$.

PFP: final plant population $\left(\mathrm{N} \mathrm{ha}^{-1}\right)$; $\mathrm{NE}$ : number of ears $\left(\mathrm{N} \mathrm{ha}^{-1}\right)$; $A P$ : plant height $(\mathrm{m})$; ElA: height of insertion of main spike (m); Grain PMS: dry grain yield (kg ha-1); Prop. stalk: stalk proportion (\% in PMST); Prop. vegetable: proportion of vegetables represented by leaves and bracts (\% in PMST); Prop. Grain: proportion of grains (\% in PMST); Prop. cob: proportion of cob (\% in PMST); Residue (kg ha-1); PMS: dry mass production (kg ha-1); Proportion (\% in PMST); Harvested $\left(\mathrm{kg} \mathrm{ha}^{-1}\right)$; Residue (kg ha-1); PMST: total dry mass productivity (kg ha-1); PMVT: total green mass productivity (kg ha-1). 
The vegetable proportion of corn (\% in PMST), consisting of leaves and bracts, was higher $(P<0.05)$ in the treatment without pigeon peas in the consortium with marandu grass because of the high dry mass production produced by corn, lower grain production, and other components in the sum of the total dry mass productivity, with no occurrence of interactions $(P>0.05)$ with the other treatments.

The proportion of grains ( $\%$ in PMST) was higher $(P<0.05)$ in the treatment in which there were pigeon peas in the intercropping of the two brachiaria; however, there was no difference between them $(P>0.05)$, resulting in the lowest participation of the vegetable portion of the corn. The participation of grains in silage from $44.8 \%$ to $52.0 \%$, with and without pigeon peas, respectively, was within the range proposed by Neumann, Figueira, Bumbieris, Ueno and Leão (2014), in which, for corn silage to assume its role as a forage resource of high nutritional value, it must represent a proportion of grains greater than $35 \%$ of the total DM of the plants.

The cutting height of $0.40 \mathrm{~m}$ above ground level of corn plants for ensilage provided greater participation of the grain fraction because of the lower proportion of stalk and senescent leaves in the ensiled mass, improving the nutritional value of the silage in relation to lower cutting heights (Caetano et al., 2012). Additionally, the higher cutting height in SIPA benefits the regrowth of grass after harvesting corn for silage (Pariz et al., 2017).

As for the productivity of the dry mass of corn, there was no significant difference $(P>0.05)$ between the consortia with and without pigeon pea beans, regardless of the brachiaria. Guimarães et al. (2017) working with corn intercropped with pigeon peas and $U$. ruziziensis for silage, also detected no difference in the accumulation of dry mass in the main crop using up to 200,000 plants per hectare of pigeon peas.

Regarding the participation of forage in total productivity, there was no difference $(P>$ 0.05 ) between the consortia. The participation of marandu grass and convert grass, without and with pigeon pea intercropping, was 0.87$1.70 \%$ and $2.05-5.18 \%$, respectively, and that of pigeon peas was $6.6-9.9 \%$ in consortium with capand-marandu and capim-convert, respectively. The small participation of forage was largely caused by the height of the harvest (0.40 m).

Garcia et al. (2016), while working with corn for silage production, with a spacing of $0.45 \mathrm{~m}$ between lines, intercropped with marandu grass, without and with dwarf pigeon beans, also found a small contribution in total productivity, with an average of $0.7 \%$ and $3.6 \%$, respectively, and values for total dry mass in the order of 28.933 and $29.349 \mathrm{~kg} \mathrm{ha}^{-1}$ for consortia, respectively, with a high share of the vegetative fraction of corn (62.3\%) in relation to grains (37.7\%).

The smaller depth of maize sowing $(0.03 \mathrm{~m})$ in relation to the fodder in consortia (0.08 $\mathrm{m})$ affected plant emergence, ensuring the higher initial development of maize by limiting competition for light, which inhibits the growth of accompanying cultures. In the partial absence of light for the brachiaria, plants showed greater height, especially in consortia with pigeon pea beans ( $P<0.05$ ), with long leaves and stalks. This behavior was verified by Gobbi, García, Garcez, Pereira and Rocha (2010), who observed an increase in the length of leaf blades and stems when the availability of light was reduced. 
The use of a legume and the brachiaria consortia with maize did not limit $(P>0.05)$ the yield of the total dry mass of maize. P. M. Costa et al. (2012) also observed the low participation of marandu grass and pulses in production for the full growth of corn plants in consortia for silage.

The residual mass at cutting did not differ $(P>0.05)$ between treatments, as well as the chemical composition in terms of DM, MM, $N D F$, and FDA, except the highest $C P$ value ( $P$ $<0.05$ ) in consortia with grass-convert (Table 4). Similar results were found by Garcia et al.
(2016), with CP content ranging from 12.3\% to $12.8 \%$ for capim-palisade in consortia with corn and without and with dwarf bean pigeon peas, respectively. N. R. Costa et al. (2017) found values of $9.3 \%$ of $\mathrm{CP}$ in the first cut of marandu grass, with a cut at $50 \mathrm{~d}$ after the removal of corn for silage. Vendramini et al. (2012), working with grass-convert in a single system, found values of 10 to $15 \%$ CP in three different periods in northern Florida, USA, because this component can vary with the age and stage of development of the plant.

\section{Table 4}

Bromatological composition of brachiaria intercropped with corn with or without pigeon pea

\begin{tabular}{|c|c|c|c|c|c|c|c|c|}
\hline \multirow[b]{3}{*}{ Variable } & \multicolumn{4}{|c|}{ Corn } & \multirow[b]{3}{*}{ EPM } & \multicolumn{3}{|c|}{ P-value } \\
\hline & \multicolumn{2}{|c|}{ Without Guandu } & \multicolumn{2}{|c|}{ With Guandu } & & \multirow[b]{2}{*}{ Consortium } & \multirow[b]{2}{*}{ Forage } & \multirow[b]{2}{*}{$C^{*} \mathrm{~F}$} \\
\hline & Marandu & Convert & Marandu & Convert & & & & \\
\hline MS & 36.71 & 38.45 & 35.55 & 32.96 & 2.39 & 0.2024 & 0.8639 & 0.3918 \\
\hline MM & 7.40 & 7.79 & 7.20 & 8.08 & 0.89 & 0.9596 & 0.4981 & 0.7865 \\
\hline FDN & 71.22 & 71.39 & 72.08 & 69.51 & 2.08 & 0.8113 & 0.5797 & 0.5282 \\
\hline FDA & 40.38 & 39.53 & 41.11 & 38.87 & 2.65 & 0.9896 & 0.5772 & 0.7998 \\
\hline PB & 11.58 & 13.94 & 12.34 & 14.08 & 0.74 & 0.5564 & 0.0245 & 0.6829 \\
\hline
\end{tabular}

LSMEANS separated by PDIFF at $5 \%$ probability.

Among the variables that affect the quality of the silage arising from the consortia (Table 5), only CP differed with the interaction $(P<0.05)$. CP content ranged from $8.0 \%$ to $9.3 \%$ in the silage consortia. The consortium in which there was the participation of pigeon beans was observed to increase the content of
$\mathrm{CP}$, but this mode differed from other consortia only with marandu grass. N. R. Costa et al. (2017) found $6.0 \%$ CP for corn silage intercropped with marandu grass. Quintino et al. (2013) reported that intercropped planting of corn with legumes increased the concentration of $\mathrm{CP}$ in silage. 
Table 5

Chemical composition of corn silages from consortia

\begin{tabular}{|c|c|c|c|c|c|c|c|c|}
\hline \multirow[b]{3}{*}{ Variable } & \multicolumn{4}{|c|}{ Corn } & \multirow[b]{3}{*}{ EPM } & \multicolumn{3}{|c|}{ P-value } \\
\hline & \multicolumn{2}{|c|}{ Without Guandu } & \multicolumn{2}{|c|}{ With Guandu } & & \multirow[b]{2}{*}{ Consortium } & \multirow[b]{2}{*}{ Forage } & \multirow[b]{2}{*}{$\mathrm{C}^{*} \mathrm{~F}$} \\
\hline & Marandu & Convert & Marandu & Convert & & & & \\
\hline MS & 36.76 & 42.00 & 38.09 & 38.52 & 1.47 & 0.4874 & 0.1267 & 0.0775 \\
\hline MM & 3.62 & 3.63 & 3.78 & 3.83 & 0.19 & 0.3797 & 0.8900 & 0.9099 \\
\hline FDN & 40.74 & 38.26 & 36.74 & 40.62 & 1.73 & 0.6568 & 0.7054 & 0.1062 \\
\hline FDA & 21.46 & 20.25 & 20.56 & 22.69 & 1.14 & 0.5326 & 0.7110 & 0.1895 \\
\hline PB & $8.00 c$ & $8.15 b c$ & $9.27 a$ & $8.52 b$ & 0.15 & 0.0002 & 0.0829 & 0.0152 \\
\hline EE & 3.29 & 2.92 & 5.53 & 5.76 & 0.79 & 0.0094 & 0.9307 & 0.7143 \\
\hline NDT & 80.09 & 80.15 & 77.65 & 80.16 & 0.84 & 0.1753 & 0.1527 & 0.1696 \\
\hline CNF & 44.43 & 47.02 & 43.84 & 40.98 & 2.60 & 0.1238 & 0.9453 & 0.1969 \\
\hline DIV & 73.31 & 73.06 & 73.07 & 73.22 & 0.12 & 0.7612 & 0.6858 & 0.1190 \\
\hline $\mathrm{pH}$ & 3.74 & 3.58 & 3.53 & 3.58 & 0.05 & 0.0831 & 0.3333 & 0.0707 \\
\hline AT & 10.15 & 10.81 & 14.20 & 15.17 & 1.65 & 0.0276 & 0.6307 & 0.9258 \\
\hline CE & 945.3 & 927.55 & 1003.83 & 977.55 & 61.7 & 0.3993 & 0.7288 & 0.9463 \\
\hline
\end{tabular}

Values with the same letter in a row do not differ from each other based on the t-test $(0.05 \%)$.

DM: dry matter (\%); MM: mineral matter (\%); NDF: neutral detergent fiber (\%); FDA: acid detergent fiber (\%); PB: crude protein (\%); EE: ethereal extract (\%); NDT: total digestible nutrients (\%); CNF: non-fibrous carbohydrates (\%); DIV: in vitro digestibility of DM (\%); pH: hydrogen potential ( $\mathrm{NaOH}$ ml); AT: titratable acidity $(\mathrm{NaOH} \mathrm{mL})$; EC: electrical conductivity $(\mu \mathrm{S}$ $\mathrm{cm}^{-1}$ at $\left.25^{\circ} \mathrm{C}\right)$.

There were no differences $(P>0.05)$ in the MS and MM contents because of the low participation of fodder in the consortium.

The participation of pigeon peas and brachiaria in the ensiled mass did not influence $(P>0.05)$ the NDF and ADF values because of the small proportion of these components and the cutting height $(0.40 \mathrm{~m})$ that resulted in a better silage quality and lower fiber content caused by the lower participation of stalks and senescent leaves.

The content of ether extract in diets for ruminants should not exceed $6 \%$ in the ingested DM to avoid negative influence on fiber degradability (Medeiros, Albertini, \& Marino, 2015). The values in this study (2.92 to $5.76 \%)$ were suitable for both silages, with higher percentages in pigeon pea silages ( $P<0.05)$, and no difference between the brachiaria used in the intercropping.

The percentage of NDT of silages (77.65-80.16\%) did not differ $(P>0.05)$ between the consortia. According to $P$. M. Costa et al. (2012), working with corn intercropping of marandu grass and legumes also found no difference because of the low participation of these components in silage. D. A. Costa et al. (2013) found $64.54 \%$ of NDT in DM in uncrossed corn silage with $0.45 \mathrm{~m}$ spacing between lines, values below those found in the present study. These values were caused by the high participation of grains in the total mass by the height of the cut $(0.40 \mathrm{~m})$. 
According to Neumann, Nörnberg, Leão, Horst and Figueira (2017), NDF is the main constituent of the vegetative portion of the silage, which has substantial importance in the final quality. With advances in the vegetative stage, there was an increase in the deposition of lignified structures in the NDF, thereby promoting a reduction in digestibility.

There was no difference $(P>0.05)$ in non-fibrous carbohydrates, in vitro digestibility, and $\mathrm{pH}$ (Table 4) in silages in relation to the consortia. The fermentation levels (3.53-3.74) of the silage obtained in the consortia were considered adequate according to Khan, $\mathrm{Yu}$, Ali, Cone and Hendriks (2015), in which pH levels between 3.0 and 4.0 were indicated for good quality silage.

Titratable acidity was closely correlated with the levels of total acidity in silages. The acidity in corn silages intercropped with pigeon peas showed higher values $(P<0.05)$ than intercropping only with the brachiaria (14.20 and $15.17 \mathrm{~mL} \mathrm{NaOH}$ ), which could be attributed to the greater buffering power of the legume (Arcanjo, Avila, Oliveira, Pereira, \& Anésio, 2016), which required a greater amount of base to for neutralization compared to silages without the inclusion of legumes.

The EC in the evaluation of silages did not specifically express which ions were present in a certain sample; however, it can contribute to the measurement of the loss of intracellular content arising from the processing of the silage. No difference was observed for silages ( $P>0.05)$, indicating that the studied forage did not show a large leakage of cellular content, and there was no difference between the values measured for effluent loss (Table 6).

\section{Table 6}

Silage losses from silages in corn intercropping with brachiaria and with or without pigeon peas

\begin{tabular}{|c|c|c|c|c|c|c|c|c|}
\hline \multirow[b]{3}{*}{ Variable } & \multicolumn{4}{|c|}{ Corn } & \multirow[b]{3}{*}{ EPM } & \multicolumn{3}{|c|}{ P-value } \\
\hline & \multicolumn{2}{|c|}{ Without Guandu } & \multicolumn{2}{|c|}{ With Guandu } & & \multirow[b]{2}{*}{ Consortium } & \multirow[b]{2}{*}{ Forage } & \multirow[b]{2}{*}{$C^{*} \mathrm{~F}$} \\
\hline & Marandu & Convert & Marandu & Convert & & & & \\
\hline Effluent & 0.75 & 0.25 & 1.13 & 0.75 & 0.33 & 0.2198 & 0.2174 & 0.8516 \\
\hline Loss TMS & 4.2 & 3.6 & 4.4 & 4.2 & 0.2 & 0.1078 & 0.0868 & 0.4396 \\
\hline
\end{tabular}

LSMEANS separated by PDIFF at 5\% probability.

Effluent (kg t MV $\left.{ }^{-1}\right)$; TMS loss: total dry matter loss (\%).

\section{Conclusions}

The consortium members did not interfere with corn productivity for silage in consortium with marandu grass and convert grass, without and with pigeon peas, showing that the modality of the integrated agricultural production system of the corn crop with the brachiarias and pigeon peas is an alternative for increasing the protein content of the ensiled material and providing greater diversity in the remaining forage. 


\section{Acknowledgments}

This study was financed in part by the Coordenação de Aperfeiçoamento de Pessoal de Nível Superior - Brasil (CAPES) - Finance Code 001. The authors thank the Conselho Nacional de Desenvolvimento Científico e Tecnológico (CNPq) for financial support.

\section{References}

Arcanjo, A. H. M., Avila Soares, N. de, Oliveira, A. R., Pereira, K. A., \& Anésio, A. H. C (2016). Silagem de leguminosas: revisão de literatura. Nutrime, 13(3), 47024710. Recuperado de https://www. nutritime.com.br/arquivos_internos/ artigos/380_-_4702-4710_-_NRE_13-3_ mai jun_2016.pdf

Association of Official Analytical Chemists (1995). Official methods of analysis. Washington, D.C.: AOAC.

Borghi, E., \& Crusciol, C. A. C. (2007). Produtividade de milho, espaçamento e modalidade de consorciação com Brachiaria brizantha em sistema plantio direto. Pesquisa Agropecuária Brasileira, 42(2), 163-171. doi: 10.1590/S0100204X2007000200004

Caetano, H., Oliveira, M. D. S. D., Freitas, J. E. D., Jr., Rêgo, A. C. D., Carvalho, M. V. D., \& Rennó, F. P. (2012). Bromatological evaluation of eleven corn cultivars harvested at two cutting heights. Revista Brasileira de Zootecnia, 41(1), 11-17. doi: 10.1590/S1516-35982012000100002

Chioderoli, C. A., Mello, L. M. de, Grigolli, P. J., Silva, J. O. D. R., \& Cesarin, A. L. (2010). Consórcio de pastagem com milho caído em plantio direto sob pivô central. EngenhariaAgrícola, 30(6), 1101-1109. doi: 10.1590/S0100-69162010000600011

Costa, D. A., Domingues, F. N., Astholpi, M. Z., Mota, D. A., Oaigen, R. P., Calonego, J., \& Miranda A. S. (2013). Influência do arranjo de plantas sobre a composição bromatológica da silagem de milho. Revista Veterinária em Foco, 10(2), 169177.

Costa, N. R., Andreotti, M., Crusciol, C. A. C., Lima, C. G. D. R., Castilhos, A. M. D., Souza, D. M. D.,... Pariz, C. M. (2017). Yield and nutritive value of the silage of corn intercropped with tropical perennial grasses. Pesquisa Agropecuária Brasileira, 52(1), 63-73. doi: 10.1590/s0100-204x2017000100008

Costa, P. M., Villela, S. D. J., Leonel, F. D. P., Araújo, S. A. D. C., Araújo, K. G., Ruas, J. R. M.,... Andrade, V. R. (2012). Intercropping of corn, brachiaria grass and leguminous plants: productivity, quality and composition of silages. Revista Brasileira de Zootecnia, 41(10), 2144-2149. doi: 10.1590/S1516-35982012001000002

Crusciol, C. A. C., Nascente, A. S., Mateus, G. P., Borghi, E., Leles, E. P., \& Santos, N. D. (2013). Effect of intercropping on yields of corn with different relative maturities and palisadegrass. Agronomy Journal, 105(3), 599-606. doi: 10.2134/agronj2012.0426

Cunha, A. R., \& Martins, D. (2009). Classificação climática para os municípios de Botucatu e São Manuel, SP. Irriga, 14(1), 1-11. doi: 10.15809/irriga.2009v14n1p1-11

Food and Agriculture Organization of the United Nations (2010). An international consultation on integrated crop-livestock systems for development: the way forward 
for sustainable production intensification. Integrated Crop Management, 13(1), 1-77.

Garcia, C. M. deP., Andreotti, M., Teixeira, M. C.M.,

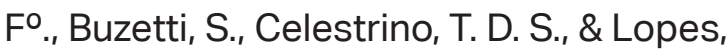
K. S. M. (2013). Desempenho agronômico da cultura do milho e espécies forrageiras em sistema de Integração LavouraPecuária no Cerrado. Ciência Rural, 43(4), 589-595. doi: 10.1590/S0103-84782013 000400005

Garcia, C. M. de P., Costa, C., Lima Meirelles, P. R. de, Andreotti, M., Pariz, C. M., \& Freitas, L. A. (2016). Wet and dry corn yield under intercrop culivation with marandu grass and/or dwarf pigeon pea and nutritional value of the marandu grass in succession. Australian Journal of Crop Science, 11(11), 1564. doi: 10.21475/ajcs.2016.10.11. PNE183

Gobbi, K. F., García, R., Garcez, A. F., Neto, Pereira, O. G., \& Rocha, G. C. (2010). Valor nutritivo do capim-braquiária e do amendoim forrageiro submetidos ao sombreamento. Archivos de Zootecnia, 59(227), 379-390.

Guimarães, F. S, Ciappina, A. L., Anjos, R. A. R. dos, Silva, A. da, \& Pelá, A. (2017). Consórcio guandu-milho-braquiária para integração lavoura-pecuária. Journal of Neotropical Agriculture, 4(5), 22-27. doi: 10.32404/rean.v4i5.221

Jaremtchuk, A. R., Costa, C., Meirelles, P. R. de L., Gonçalves, H. C., Ostrensky, A., Koslowski, L. A., \& Madeira, H. M. F. (2008). Produção, composição bromatológica e extração de potássio pela planta de milho para silagem colhida em duas alturas de corte. Acta Scientiarum. Agronomy, 28(3), 351-357. doi: 10.4025/actasciagron. v28i3.955
Jobim, C. C., Nussio, L. G., Reis, R. A., \& Schmidt, P. (2007). Methodological advances in evaluation of preserved forage quality. Revista Brasileira de Zootecnia, 36(Suppl.), 101-119. doi: 10.1590/S1516-35982007 001000013

Kappes, C., \& Zancanaro, L. (2015). Intercrop systems of brachiaria and crotalarias with, maize crop. Revista Brasileira de Milho e Sorgo, 14(2),219-234.doi:10.18512/19806477/rbms.v14n2p219-234

Khan, N. A., Yu, P., Ali, M., Cone, J. W., \& Hendriks, W. H. (2015). Valor nutritivo da silagem de milho em relação ao desempenho e qualidade do leite. Jornal da Ciência da Alimentação e Agricultura, 95(2), 238-252. doi: 10.1002/jsfa.6703

Kluthcouski, J., Cobucci, T., Aidar, H., Yokoyama, L. P., Oliveira, I. P. de, Costa, J. D. S.,... Magnabosco, C. D. U. (2000). Sistema Santa Fé-Tecnologia EMBRAPA: integração lavoura-pecuária pelo consórcio de culturas anuais com forrageiras, em áreas de lavoura, nos sistemas direto e convencional. (Circular Técnica INFOTECA-E). Santo Antônio de Goiás, GO, EMBRAPA Arroz e Feijão.

Medeiros, S. R., Albertini, T. Z., \& Marino, C. T. (2015). Lipídios na nutrição de ruminantes. Nutrição de bovinos de corte Fundamentos e aplicações. Brasília, DF. EMBRAPA.

Mhlanga, B., Cheesman, S., Maasdorp, B., Mupangwa, W., Munyoro, C., Sithole, C., \& Thierfelder, C. (2016). Effects of relay cover crop planting date on their biomass and maize productivity in a sub-humid region of Zimbabwe under conservation agriculture. NJAS-Wageningen Journal of Life Sciences, 78(09), 93-101. doi: 10.1016/j.njas.2016.05.001 
National Research Council (2001). Nutrient requirements of dairy cattle (7nd ed.). Washington, D.C.: National Academic Press.

Neumann, M., Figueira, D. N., Bumbieris, V. H., Jr., Ueno, R. K., \& Leão, G. F. M. (2014). Ensilagem: estratégias visando maior produção de leite. Anais do Simpósio Brasileiro de Ruminantes Leiteiros, Uberlândia, MG, Brasil, 1.

Neumann, M., Nörnberg, J. L., Leão, G. F. M., Horst, E. H., \& Figueira, D. N. (2017). Chemical fractionation of carbohydrate and protein composition of corn silages fertilized with increasing doses of nitrogen. Ciência Rural, 47(5), 1-7. doi: 10.1590/0103-8478cr20160270

Oliveira, P. D., Kluthcouski, J., Favarin, J. L., \& Santos, D. D. C. (2011). Consórcio de milho com braquiária e guandu-anão em sistema de dessecação parcial. Pesquisa Agropecuária Brasileira, 46(10), 1184-1192. doi: 10.1590/S0100204X2011001000010

Pariz, C. M., Costa, C., Crusciol, C. A., Castilhos, A. M., Meirelles, P. R., Roça, R. O.,... Yasuoka, J. I. (2017). Lamb production responses to grass grazing in a companion crop system with corn silage and oversowing of yellow oat in a tropical region. Agricultural Systems, 151(2), 1-11. doi: 10.1016/j.agsy. 2016.11.004

Pereira, R. G., Albuquerque, A. W. D., Souza, R. D. O., Silva, A. D. D., Santos, J. P. A. D., Barros, E. D. S., \& Medeiros, P. V. Q. D. (2011). Sistemas de manejo do solo: soja [Glycine max (L.)] consorciada com Brachiaria decumbens (STAPF). Pesquisa Agropecuária Tropical, 41(1), 44-51. doi: 10.5216/pat.v4 i1. 6981
Quintino, A., Zimmer, A. H., Costa, J. A. A. da, Almeida, R. G. de, \& Bungenstab, D. J. (2013). Silagem de milho safrinha com níveis crescentes de forragem de guandu. In EMBRAPA Gado de Corte-Resumo em anais de congresso. In Simpósio de Produção Animal a Pasto, 2, Londrina. [Resumos...]. Maringá: Nova Sthampa; Londrina: Universidade Estadual de Londrina, SIMPAPASTO.

Raij, B. V., Andrade, J. C., Cantarella, H., \& Quaggio, J. A. (2001). Análise química para avaliação da fertilidade dos solos tropicais. Campinas: Instituto Agronômico de Campinas.

Raij, B. V., Cantarella, H., Quaggio, J. A., \& Furlani, A. M. C. (1997). Recomendações de adubação e calagem para o Estado de São Paulo (Vol. 285). Campinas: Instituto Agronômico/Fundação IAC.

Santos, H. G., Jacomine, P. K. T., Anjos, L. H. C. dos, Oliveira, V. A. de, Lumbreras, J. F., Coelho, M. R.,... Cunha, T. J. F. (2018). Sistema brasileiro de classificação de solos. Brasília, DF: EMBRAPA.

Santos, M. C., Nussio, L. G., Mourão, G. B., Schmidt, P., Mari, L. J., \& Ribeiro, J. L. (2008). Influência da utilização de aditivos químicos no perfil da fermentação, no valor nutritivo e nas perdas de silagens de cana-de-açúcar. Revista Brasileira de Zootecnia, 37(9), 1555-1563. doi: 10.1590/ S1516-35982008000 900006

Silva, D. J., \& Queiroz, A. C. (2002). Análises de alimentos: métodos químicos e biológicos (3a ed.). Viçosa, MG: Editora UFV.

Statistical Analysis System Institute (2014). Base SAS 9.4 Procedures Guide. Cary, NC: SAS Institute. 
Van Soest, P. J. (1994). Nutritional ecology of the ruminant (2nd ed.). Ithaca, NY: Comstock Publishing Associates/Cornell University Press.

Vendramini, J. M. B., Sollenberger, L. E., Lamb, G. C., Foster, J. L., Liu, K., \& Maddox, M.
K. (2012). Forage accumulation, nutritive value, and persistence of 'Mulato Il'brachiariagrass in northern Florida. Crop Science, 52(2), 914-922. doi: 10.2135/ cropsci2011.06.0338 
